\title{
Worldwide Tax Revenue Collection: Lessons from Pre- Pandemic Era
}

\author{
Ahmad Zaky Zamani ${ }^{\alpha}$ \\ *Email: u829271a@ecs.osaka-u.ac.jp \\ a Osaka School of International Public \\ Policy Osaka University 1-31 \\ Machikaneyamacho, Toyonaka, Osaka \\ Japan 560-0043 \\ Riwayat artikel: \\ - Diterima 15 September 2020 \\ - Direvisi 25 Oktober 2020 \\ - Disetujui 8 Desember 2020 \\ - Tersedia online Maret 2021
}

\begin{abstract}
Despite the fact that the majority of countries in the world rely heavily on tax revenue, there is a vast difference in terms of tax collection performance. This study revisited several structural, economic, demographic, and institutional factors that potentially explain the variation. We employ standard OLS, fixed effect, and system GMM estimations to analyze panel data of 161 countries for 15 years spanning from 2002 to 2017. Our findings confirmed that the level of development and investment are among key factors that lead to revenue improvement. It is very likely that such a relationship has two-way directions. Other factors such as trade openness, inflation, the agriculture sector's share (as a proxy of the informal economy), national resources, population, and governance cannot be downplayed despite its mixed inferences.

Keywords:

tax ratio, structural and institutional factors, governance, panel data analysis

JEL Classification:

$\mathrm{H} 11, \mathrm{H} 10$
\end{abstract}




\section{BACKGROUND}

The recent calamity of the COVID-19 pandemic has forced many countries to raise more nontaxation funding, including bond issuance, as tax revenues were dwindling due to economic activities slow down. However, taxation will still be the most essential source of national revenues in the next foreseeable future.

Compared to the overall size country's economy, the amount of collected tax revenue is called tax to GDP ratio, often simply termed as tax ratio. It is an essential metric needed by policymakers and analysts to track annual receipts from taxation. Tax ratio also serves as an important indicator of economic condition, direction, and impact of governments policies over time. A very high tax ratio indicates a heavy reliance on taxation and more state's involvement in public matters. Contrary, a low tax ratio can be a sign of a country being "tax heaven", having low taxing power and capacity to collect taxes, or suffering other economic maladies. When a country has a stable tax ratio, the tax revenue increase on par with economic growth. On the other hand, a drop in tax ratio means that revenue collection lags behind the economy. Its importance and complexity have made static and dynamic interpretation of tax ratio an object of interest from many perspectives.

Why some countries have a significantly high tax ratio while many others keep staying at a very low level? What factors could potentially represent the variation in different countries? Past studies on this topic have arrived with some common findings. The vast majority of cross-country analysis concluded that structural factors played the most important role in determining a country's tax ratio. Among these factors are the country's level of development, economic structure, monetary and fiscal policy, economic activities, and demographic variables. More recently, scholars also added several non-economic factors, for example, political regime, democracy, security, and various societal indicators.

However, mixed and contradictory results were also arising at some points. Therefore, this study attempts to contribute to the discourse. We use standard empirical analysis i.e., pooled OLS, fixed effect, and generalized method of moments to ensure comparability with previous studies. To add more weight, we analyze a much larger number of countries in our pool, using a recent and updated dataset, and include investment variable that was rarely touched before.

The next part of this paper is a brief literature review of previous works on this field. In the following section, we describe our empirical strategy and data source. Then, we discuss our findings, such as facts, figures, trends, and statistical inferences. Lastly, we offer concluding remarks and recommendations.

\section{LITERATURE REVIEW}

Classic studies on tax revenue date back many decades ago. Lotz \& Morss's (1967) study is one of the earliest attempts to explain the cross-country variation of tax revenue. Their simple empirical analysis concluded that GNP and trade share (export and import) are significant factors determining the level of tax revenue. Chelliah, Baas, \& Kelly (1975) then extended the study using the agriculture sector share in the economy instead of GNP per capita and included mineral production (and its export proportion).

Since then, many other studies were conducted with various results. The variety of the studies was due to differences in the scope, scale, and strategy. The majority of the studies focus on economic variables, but the long list of variables was not uniform. Many strands of earlier studies also concentrated only on a partial sample of countries globally, for example, only focusing on developing/advanced countries or a specific region.

The other variation also came from empirical methods. In spite of this, the consensus is to use more than one method to have an alternative comparison. Most studies use either cross-section OLS regression, fixed/random effect method, or generalized method of moments (GMM) 
estimators. The last difference is in the choice of the analyzed period. In this case, panel data with more than a 10-year period is preferred by the mainstream.

One particular study in this regard is conducted by Khujamkulov (2016). He focused on 33 transitional countries during 1991-2014 while emphasizing tax structures in those economies. Using fixed effect and GMM estimators, he found national income, degree of openness, the share of the non-agricultural sector, population growth, urbanization, population density, the proportion of the younger population, and the employment rate, all positively correlated with the tax ratio.

Recently, Yogo \& Njib (2018) explores the relationship between political competition and tax revenues in 89 developing countries from 1988 to 2010. They conducted dynamic panel data analysis using the two-step system GMM. They concluded that political competition positively and significantly affects total tax revenues. Nonetheless, they note that the general pattern slightly differs across the type of taxes, and the net effect of political competition on tax revenues is negative for countries that have adopted fiscal rules.

Contemporary studies also include governance considerations as an important factor that could explain the difference in tax revenue across countries with more or less similar economic outlook. Kaufmann et al. (2007) broadly define governance as "a set of traditions and institutions by which authority in a country is exercised. This broad definition includes the process by which governments are selected, monitored and replaced, the capacity of the government to effectively formulate and implement sound policies, and the respect of citizens and the state for the institutions that govern economic and social interactions among them." Syadullah \& Wibowo (2015) have attempted to scrutinize the governance and taxation relationship, focusing on the ASEAN region. A more recent analysis by Castañeda Rodríguez (2018) has also included these factors in his worldwide unbalanced panel study, along with ample other variables.

Bird, Martinez-vazquez, \& Torgler (2014) found evidence supporting societal institution significance, especially in developing countries. Governance indices represent societal institution factors. Gupta (2007) and later Ajaz \& Ahmad (2010) also arrived at a more or less similar conclusion that governance matters along with other structural variables. They argued that revenue generation in developing countries is hampered by corruption in tax administration and low governance quality. Using dynamic panel data analysis of 25 developing countries over the period 1990-2005, they found empirical evidence that corruption has an adverse effect on tax collection, while good governance contributes to better performance.

\section{METHODOLOGY}

Baseline Specification

Our baseline analysis will be conducted using pooled OLS regression. This simple method was mainly performed under the assumption that the endogeneity issue is not severe. Early studies in this field like Lotz \& Morss (1967) and Chelliah et al. (1975) used OLS due to the level of econometrics technique and limited computing power at that time. Nevertheless, more recent studies still applied OLS as a single method like Bird, Martinez-vazquez, \& Torgler (2014) or paired it with other methods for comparison purposes, for example, Grigorian \& Davoodi (2007).

We use the following basic model to estimate tax revenue:

\section{TR=f(GDPPC, CAP, OPEN, INF, AGRI, NATRES, POP, GOV)}

TR stands for tax ratio or share of tax revenue to GDP. This study chose to use aggregate tax revenue (national and local taxes), excluding social security contributions. The exclusion is decided in order to gain better comparability between countries due to the fact that the 
majority do not have social security in place.

GDPPC (GDP per capita) represents the level of development. Ample studies have shown that a higher level of development corresponds to advanced economic activities that generate a more significant share of taxable objects. At the same time, higher-income directly indicates a higher ability to pay taxes. This indication is a prerequisite in collecting a larger sum of tax revenue. Thus GDP per capita would have a positive effect on the tax ratio.

CAP denotes Gross Capital Formation share to GDP. The World Bank formerly uses gross domestic investment as the term to reflect the country's annual addition to the economy's fixed assets plus net changes in the level of inventories and net acquisitions of valuables. It is an essential component when calculating GDP from the expenditure side since it captures the private and public sectors' investment levels. It includes land improvements, plants, machinery, and equipment, buildings, and other construction works. The majority of the activities are related to taxation collection through direct and/or indirect taxes. Therefore, we expect that higher capital formation will boost tax revenue.

OPEN reflects the country's trade openness indication. It is the sum of external trade volume (exports and imports) of goods and services as a GDP percentage. Since international trade is much easier to tax than other sectors, many countries rely on this activity to collect taxes, especially in developing countries. Despite the trend showing a decreasing reliance on trade taxes, openness still plays an important role in advanced countries' economies. It stimulates value-added improvement and job creation along the process. In turn, it is expected to have a positive impact on tax revenue.

INF is an annual inflation rate that represents monetary policy standpoint and fiscal policies to some extent. As the price of goods and services increases, wages are likely to go up too. Since the revenue from goods and services taxes (GST) or value-added taxes (VAT) is highly dependent on the price level, while wages directly affect income taxes, it is natural that inflation would push the tax ratio upward. However, the opposite effect may take place when a combination of high inflation, long lags of collection, and low elasticity of income occurs. The so-called "Tanzi effect" was first pointed out by Tanzi (1977). Recent findings concur that inflation is likely to bring more negative impact than positive, for example, Agbeyegbe, Stotsky, \& WoldeMariam (2004) and Baunsgaard \& Keen (2010). Hence, we also presume that we will find the negative sign of inflation in our model.

AGRI is the relative share of agriculture, forestry, and fishing sectors to GDP. This sector-wise factor is found to have a negative impact on tax revenue collection. The typical argument is that these sectors are among the hard-to-tax groups, especially when a large number of the population work as subsistent farmers or fishers. According to the latest study by ILO (2018), informal employment in the agriculture sector is at $93.6 \%$, the highest level worldwide. This event reasonably justifies that proportion of these sectors could serve well as a proxy measurement of an informal economy. Some countries are exempt from taxes, a large share of agricultural activities for political reasons (Ajaz \& Ahmad, 2010). A higher agricultural share in GDP would lead to a lower level of tax ratio.

NATRES stands for natural resources rent as a percentage of GDP. These natural resources include oil, gas, mineral, coal, and forest a country endowed. Natural resource-rich countries might have less incentive to mobilize revenue from taxation. Yogo \& Njib (2018) found an indication of that crowding-out effect with regards to oil income. We also hypothesize that the overall accumulation of natural resources could have a negative impact on tax receipts.

POP is total population estimates representing the demographic factor. A larger population reflects a higher number of economic players from the supply side, thus increasing 
the economy's size. In spite of this, Bahl (2004) and Baunsgaard \& Keen (2010) warned that there is also a possibility that tax systems may lag behind in the ability to capture new taxpayers. In this case, the net effect of population on tax ratio could be negative.

GOV denotes a broad spectrum of governance indicators. It ranges from voice and accountability, political stability, government effectiveness, regulatory quality, the rule of law, and corruption control. All of those sub-indices and its overall level could help explain tax ratio differences worldwide. We believe that every aspect of good governance would improve tax performance.

We use two-tier empirical analysis i.e. all countries worldwide and sub-samples by income level. The regressions were also performed using two types of specifications. First, using only structural (economic and demographic) variables, then institutional (governance) variables are added in the later analysis.

Advanced analysis (Fixed effect and System GMM)

Understanding that using only pooled OLS could lead to biased conclusions due to unobserved factors, we complement our baseline analysis with fixed effect specifications. It is conducted under the assumption that the explanatory variables do not capture certain country-specific characteristics and that these are uncorrelated with the error term. A similar strategy was also carried out by Gupta (2007). Our fixed effect specification departs from the baseline model:

『TR】_it $=\alpha_{-}$it $+\llbracket \beta X \rrbracket \_i t+\llbracket \gamma Z \rrbracket i_{-}+\delta_{-} t+\varepsilon_{-}$it

where TR is tax to GDP ratio in a country i during year $t, \alpha$ is country's and fixed effect, $X$ is the vector of aforementioned structural or economic variables (GDP per capita, gross capital formation, openness, inflation, agriculture share, natural resources, and population), and $Z$ is the governance indicators (as overall and sub-indices), $\delta$ is the time fixed effect and $\varepsilon$ is the error term.

As an additional measure to tackle endogeneity concerns and country-specific effects, we proceed with the analysis using system Generalized Method of Moments (GMM) as proposed by Blundell $\&$ Bond (1998), an augmentation of earlier difference GMM version by Arellano \& Bond (1991). Since the tax ratio level does not change drastically over time, system GMM is preferred over difference GMM. This method uses internally generated instruments from potentially endogenous regressors. It combines the estimation using two forms of instruments i.e. lagged level and first differences. This approach was also employed by Gupta (2007) and McNabb (2018). While using partially similar method with Castañeda Rodríguez (2018), our analysis prefers a more balanced panel data, inclusion of more countries, and fewer array of variables.

Data

This study uses publicly available data from different sources. The tax revenue to GDP ratio is obtained from the Government Revenue Dataset (GRD) produced by the International Centre for Tax and Development (ICTD) - United Nations University (UNU). This particular dataset is superior compared to others that it is more carefully compiled, merged, and cleaned to improve its quality. Its structure allows inclusion or exclusion of tax revenue by type of taxes, government level, and revenue source (Prichard, 2016).

The set of structural variables i.e. GDP per capita, export and import (trade openness), gross capital formation, inflation, the sectoral composition of GDP, national resources rents, and population, are all acquired from the World Bank's World Development Indicators (WDI). 
We utilize Worldwide Governance Indicators (WGI), which were first developed in 1999 by Daniel Kaufmann, Aart Kraay, and Zoido-Lobaton from the World Bank Institute as the source of cross-country governance measures. WGI reports on six broad dimensions of governance i.e. Voice and accountability (VA), Political stability and absence of violence (PV), Government effectiveness (GE), Regulatory quality (RQ), Rule of law (RL), and Control of Corruption (CC). A brief explanation of these indices is summarized in the Appendix. Taking data availability into consideration, we use the WGI dataset that contains panel data for over 200 countries and territories over the period of 1996-2018.

After performing standard data management, we merged the datasets containing information of interests for 217 countries. However, due to missing values in several points, ultimately, we cover 167 countries in our analysis. For the same reason, we limit our time analysis to a 15-year period (2002-2016). Consequently, we roll back to the earlier World Bank income classification list instead of the most recent one (FY 2020). This classification is by far the largest cross-country empirical study in this subject to the best of our knowledge.

\section{RESULTS AND DISCUSSION}

Our preliminary observation on the population statistics indicates mixed vindications towards the hypotheses. Figure 1 below shows the tax ratio correlates strongly positive with the level of development. A higher tax ratio is likely to be found in countries with higher GDP per capita. From 2002 to 2017, welfare states like Scandinavian countries consistently dominate the top bracket. 7 out of the top 10 are advanced countries. Denmark has the highest average tax ratio with more than 45\%, followed by Lesotho, Angola, Cuba, New Zealand, Sweden, Iceland, Norway, Finland, and Belgium.

On the contrasting side, the lowest quartile is dominated by a mix of resource-rich countries and conflict zones. Iraq, which booked less than $1 \%$ tax receipt in the last 15 years, is at the bottom. The other low ones include Kuwait, Somalia, Saudi Arabia, Bahrain, Oman, Qatar, Libya, Myanmar, and Iran (complete worldwide ranking in Appendix). Note that countries with zero tax ratios are intentionally excluded from the list.

FIGURE-1 Tax ratio and level of development

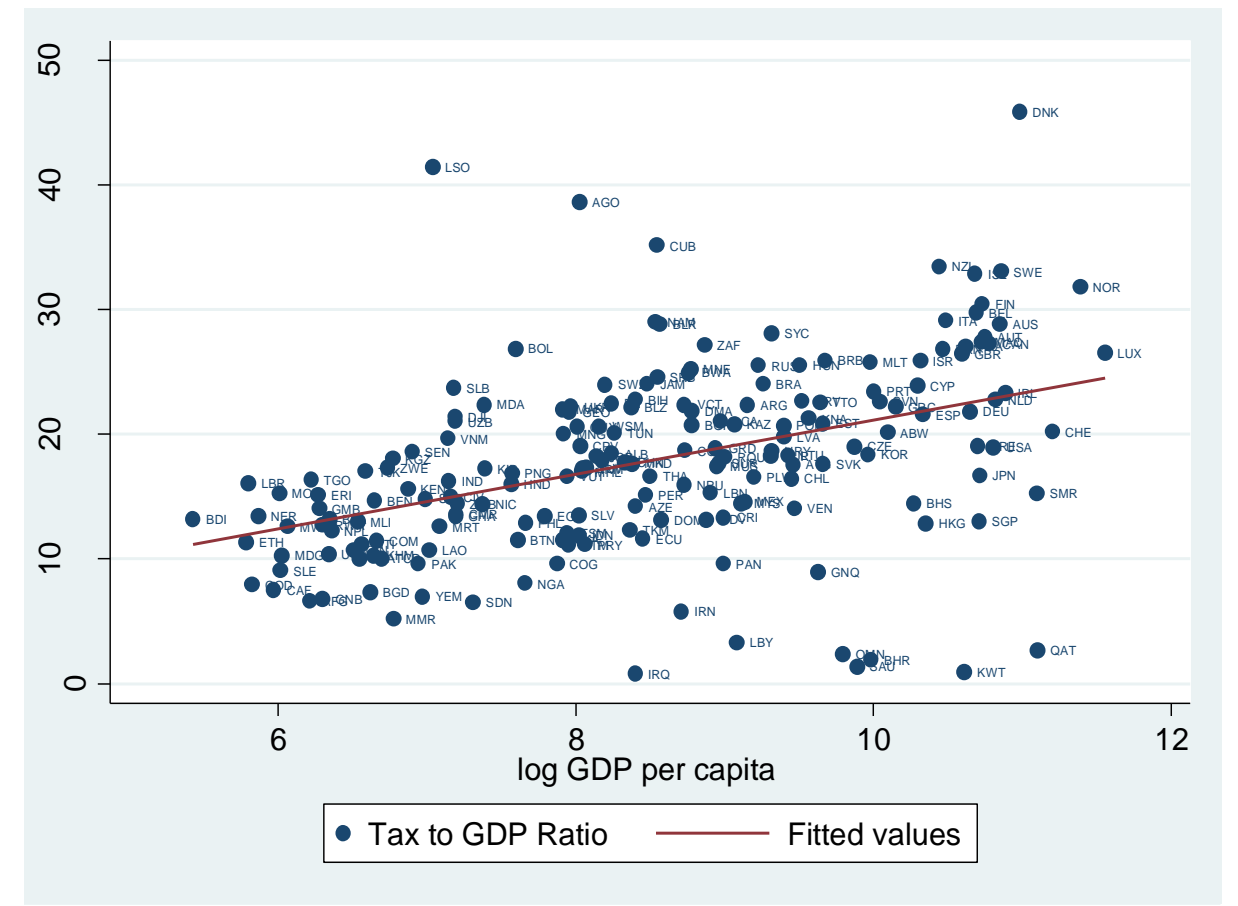

Source: Author's calculation (2002-2017 average) 
Based on the pairwise correlation matrix, we found that the agriculture share, natural resource rents, and population negatively associate with the tax ratio (see Appendix for more details). This result fits our earlier supposition. Other factors, such as inflation, openness, capital formation, and governance, all have a positive correlation. However, when using the average country-wise plot, we found that countries with higher inflation are more likely to have a lower tax ratio. Meanwhile, capital formation seems to have a slightly negative correlation.

Breaking down by income level brackets, high-income countries collect tax revenue above $20 \%$ of their GDP. To be more precise, the average level for this group is $21.36 \%$. The correlation between income and tax ratio becomes more apparent when we look into the other income groups. Uppermiddle and lower-middle-income countries have on average $18.11 \%$ and $16.67 \%$, respectively. Lowincome countries performed much lower at $11.97 \%$.

FIGURE-2 Tax ratio trends by country income level

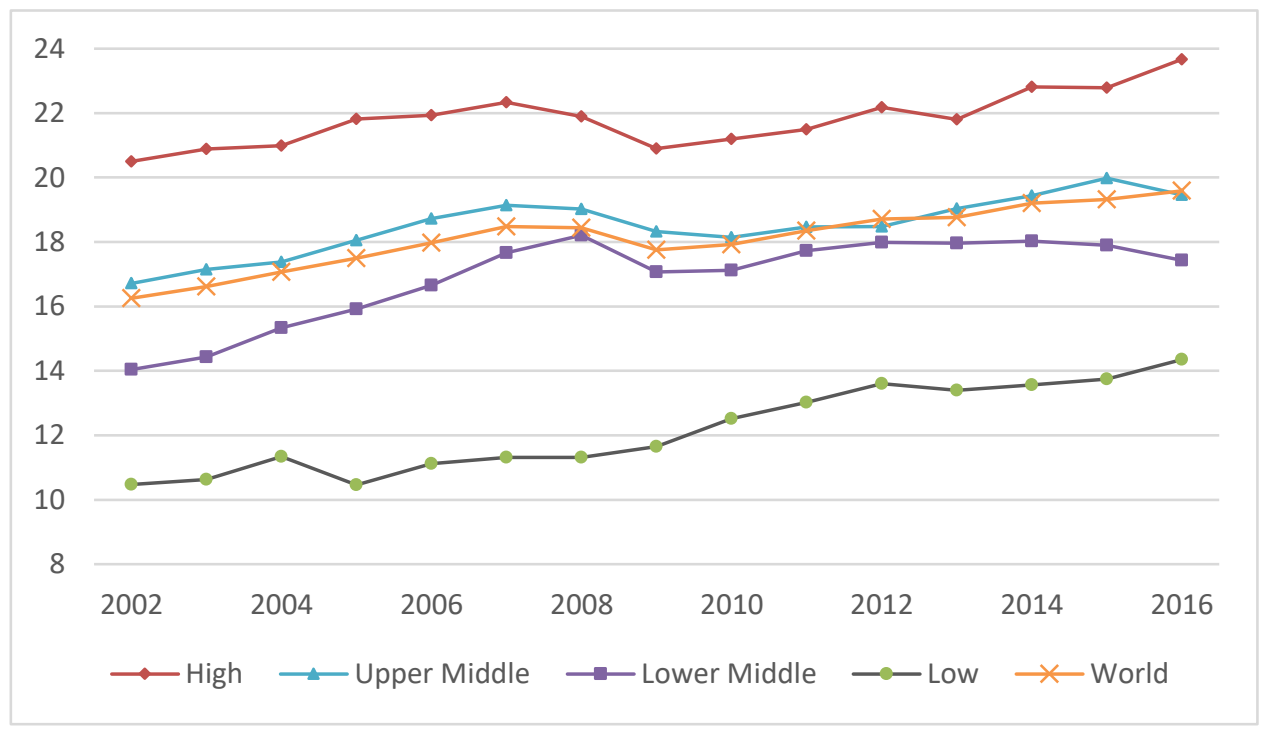

Source: Author's calculation based on GRD-ICTD dataset

The average level for low-income countries is admittedly low. In spite of this, the tax ratio in these countries has been growing faster than in middle and high-income countries. In 2002, the ratio was slightly above $10 \%$ (Figure 2). The current level surpassed $14 \%$ in 2016 . While the worldwide tax ratio declined during 2008-2009, low-income countries even performed better. The middle-income countries at first showed rapid progressivity prior to the financial crisis, but while the high-income made a swift recovery, their tax collection stalled ever since.

In the meantime, the world average has been in increasing trend. This tendency is very likely due to the improvement in the high and low-income countries. We should note that tax reforms that have been undergone in many parts of the world augment this upward movement.

When we conduct regional analysis, it is not surprising to find countries in Europe (EU) and North America (NA) have significantly high tax ratios (see Figure 3). The contraction of fiscal policies and economic outlook in the last decade in the USA has driven the ratio down. In contrast, Europe still improves its tax revenue but at a more modest rate. East Asia and the Pacific (EA) region experience a relatively flat ratio until recently.

The rest of the world saw a substantial upturn in tax ratio. It is interesting to see the countries in the Middle East and North Africa (MENA) and South Asia boost their tax revenue rapidly. On average, these countries have exceeded $12 \%$ or more than a $2 \%$ increase in the last six years. Countries in Latin America and Caribbean (LAC) and Sub-Sahara Africa (SSA) also grow steadily. 
FIGURE-3 Tax ratio by regions

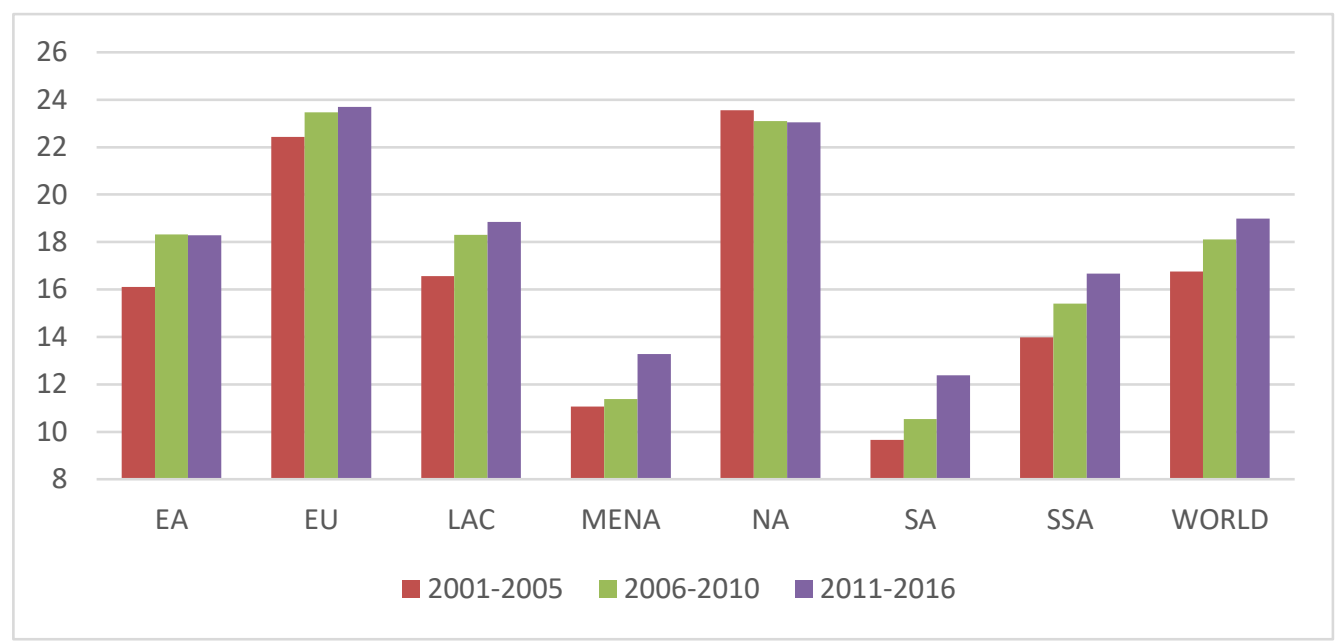

Source: Author's calculation based on GRD-ICTD dataset

By conducting a further inspection of the correlation between variables, we notice that the relationship among governance indices is very high. The range between six indices varies from 0.6 to more than 0.9 . These high correlation values are most likely due to the WGI method combining various primary data sources into uniform scores. We agree with Bird et al. (2014) as well as Gupta (2007) to use highly correlated variables in separate specifications instead of pooling them into a model. In so doing, we could avoid potential multicollinearity and bias that may arise if we put all governance indicators in the same specification.

FIGURE-4 Tax ratio and overall governance

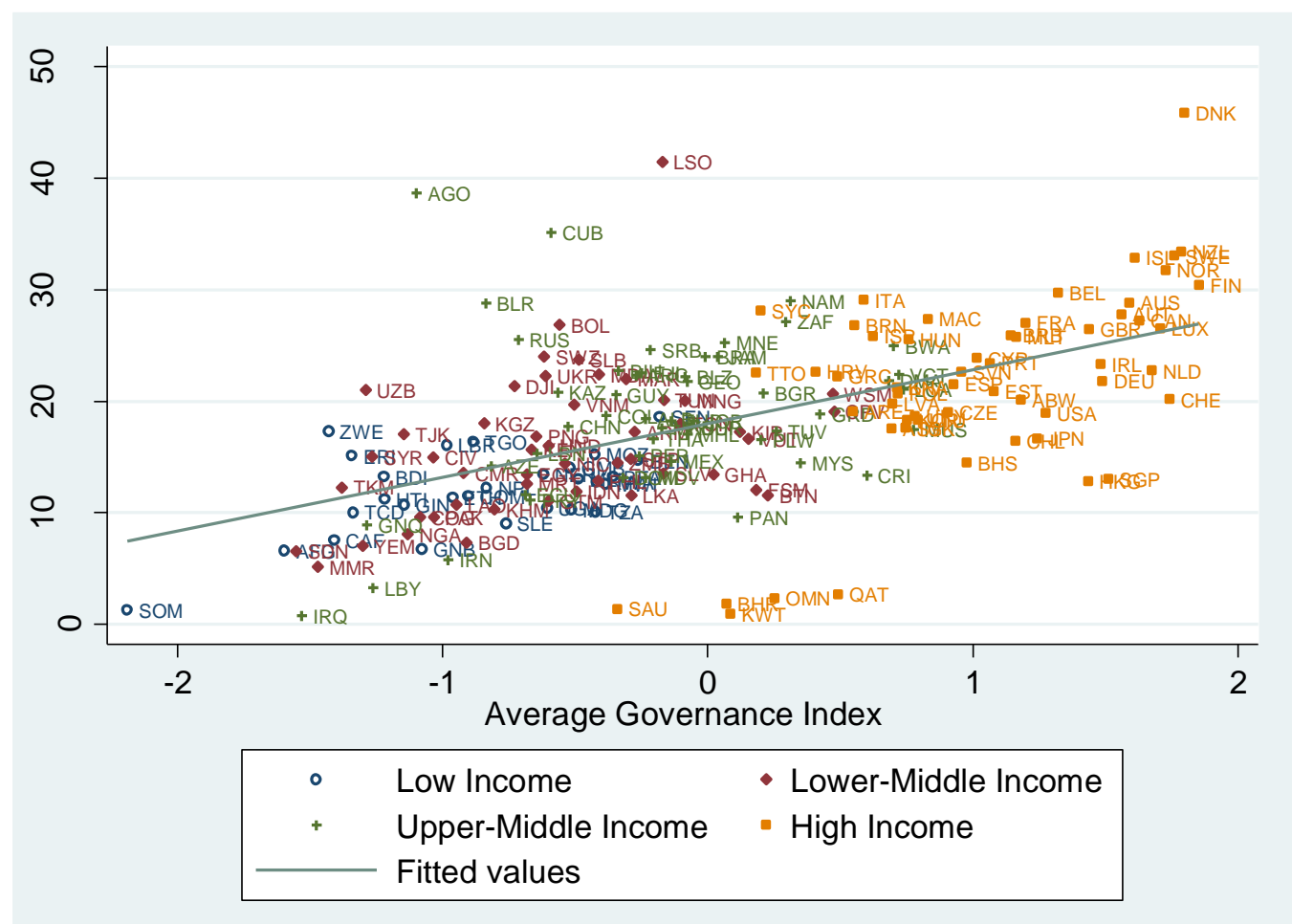

Source: Author's calculation based on GRD-ICTD \& WGI dataset 


\section{Empirical Analysis}

Our baseline specifications using pooled OLS show that all explanatory variables are significant in determining tax ratio level except for inflation and agriculture share. However, we should note that the addition of governance indicators in our regression alters the sign or magnitude of structural variables (see Table l). GDP per capita has a positive and the largest influence on tax ratio compared to other economic variables. As expected, trade openness also has a positive impact with and without the governance factor.

It is interesting to find that capital formations have a negative impact on both specifications, while inflation has a positive sign. This result is a contradiction to our earlier prediction. At the same time, natural resource endowment and population size could bring downward pressure. It explains why taxation has never become the first priority for most Middle East countries. While China and India have an unexceptional tax ratio level, other populous countries like Indonesia, Pakistan, Bangladesh, and Nigeria have sustained a below-average tax ratio for years. These factors' cumulative impact contributes to a $0.4 \%$ difference in the worldwide tax ratio variation, almost offsetting the income factor's positive impact. In total, other structural factors only contribute marginally small at around $0.1 \%$ of the tax ratio.

By keeping all structural variables as independent variables, we proceed to investigate the impact of each governance indicator. Overall governance turns out to be the most influential factor, while all structural factors do not vary significantly in each specification. It suggests that improving the governance index by 1 point in the range of 5 points scoring system could be associated with a $3.1 \%$ increase in tax to GDP ratio. By the same token, better control of corruption also has an equivalent impact. This result is in line with the previous studies' findings (Gupta, 2007; Bird et al., 2014; Castañeda Rodríguez, 2018). Another considerably high governance indicator is government effectiveness with a $2.8 \%$ impact. Political stability and security, voice and accountability, and the rule of law are also a significant factor but with half the magnitude of the preceding governance measures. Meanwhile, a regulatory quality that has a third of overall governance impact does not seem to play an important role in this discourse.

In order to overcome several limitations of the baseline specifications that were run using OLS regressions, we combine our analysis with fixed effect and system GMM. These methods were employed as robustness and sensitivity checks. In Table 1 that summarized our findings, it is evident that in most cases, the direction of each variable still consistent with the baseline (more detailed estimation results are presented in the Appendix). The most noticeable differences are the magnitude and significance.

TABLE-1 Summary of regression results

\begin{tabular}{lcccccc}
\hline & $\begin{array}{c}(1) \\
\text { Pooled } \\
\text { OLS }\end{array}$ & $\begin{array}{c}(2) \\
\text { Pooled } \\
\text { OLS }\end{array}$ & $\begin{array}{c}(3) \\
\text { Fixed } \\
\text { Effect }\end{array}$ & $\begin{array}{c}\text { (4) } \\
\text { Fixed } \\
\text { Effect }\end{array}$ & $\begin{array}{c}\text { (5) } \\
\text { System } \\
\text { GMM }\end{array}$ & $\begin{array}{c}\text { (6) } \\
\text { System } \\
\text { GMM }\end{array}$ \\
\hline log GDP per capita & & & & & & \\
& $2.156^{* * *}$ & $0.470^{* *}$ & $2.798^{* *}$ & $2.914^{* *}$ & $0.565^{*}$ & 0.347 \\
Gross Capital Formation (\% to GDP) & $(0.184)$ & $(0.231)$ & $(1.266)$ & $(1.257)$ & $(0.330)$ & $(0.455)$ \\
& $-0.039^{* *}$ & $-0.054^{* * *}$ & $0.064^{* * *}$ & $0.064^{* * *}$ & $0.031^{* *}$ & $0.032^{* *}$ \\
Trade Openness & $(0.016)$ & $(0.017)$ & $(0.021)$ & $(0.021)$ & $(0.015)$ & $(0.015)$ \\
& $0.018^{* * *}$ & $0.014^{* * *}$ & 0.006 & 0.005 & 0.000 & 0.001 \\
Inflation (\%, annual) & $(0.005)$ & $(0.005)$ & $(0.009)$ & $(0.009)$ & $(0.008)$ & $(0.009)$ \\
& 0.023 & $0.049^{* * *}$ & -0.009 & -0.009 & 0.021 & 0.023 \\
Agriculture, Fishing and Forestry (\% to GDP) & $(0.017)$ & $(0.018)$ & $(0.010)$ & $(0.010)$ & $(0.023)$ & $(0.024)$ \\
& -0.026 & $-0.077^{* * *}$ & -0.070 & -0.073 & 0.009 & -0.008 \\
Total Natural Resources Rents (\% to GDP) & $(0.021)$ & $(0.021)$ & $(0.055)$ & $(0.056)$ & $(0.044)$ & $(0.048)$ \\
& $-0.217^{* * *}$ & $-0.157^{* * *}$ & 0.019 & 0.015 & -0.020 & -0.032 \\
log Total Population & $(0.016)$ & $(0.017)$ & $(0.032)$ & $(0.032)$ & $(0.022)$ & $(0.024)$ \\
& $-0.200^{* * *}$ & $-0.128^{*}$ & 3.042 & 2.836 & 0.168 & 0.074
\end{tabular}




\begin{tabular}{|c|c|c|c|c|c|c|}
\hline & $(0.077)$ & $(0.076)$ & $(2.104)$ & $(2.138)$ & $(0.169)$ & $(0.163)$ \\
\hline \multirow[t]{2}{*}{ Overall Governance } & & $3.128^{* * *}$ & & -0.283 & & 0.189 \\
\hline & & $(0.308)$ & & $(0.857)$ & & $(0.450)$ \\
\hline \multirow[t]{2}{*}{ Tax to GDP Ratio (Lagl) } & & & & & $0.892^{* * *}$ & $0.875^{* * *}$ \\
\hline & & & & & $(0.037)$ & $(0.042)$ \\
\hline \multirow[t]{2}{*}{ Constant } & $4.282^{*}$ & $18.149^{* * *}$ & -55.282 & -52.796 & -6.168 & -2.786 \\
\hline & $(2.432)$ & $(2.744)$ & (36.174) & $(36.868)$ & $(4.921)$ & $(5.653)$ \\
\hline Observations & 2,147 & 2,116 & 2,147 & 2,116 & 1,991 & 1,964 \\
\hline $\mathrm{R}$-squared & 0.400 & 0.427 & 0.213 & 0.205 & & \\
\hline Number of countries & & & 163 & 161 & 162 & 160 \\
\hline Number of Instruments & & & & & 138 & 152 \\
\hline AR 2 & & & & & 0.0939 & 0.0872 \\
\hline AR 3 & & & & & 0.203 & 0.183 \\
\hline Hansen J & & & & & 125 & 134.8 \\
\hline Country FE & & & YES & YES & & \\
\hline Year FE & & & YES & YES & & \\
\hline
\end{tabular}

Robust standard errors in parentheses

**** $\mathrm{p}<0.01,{ }^{* *} \mathrm{p}<0.05,{ }^{*} \mathrm{p}<0.1$

Both fixed-effect and two-step system GMM specifications imply that GDP per capita still plays a significant role in determining tax ratio. The fixed-effect estimated even results in a larger size than OLS estimation. After controlling country and time-specific fixed-effect, we confidently confirm that the tax ratio would also surge as the level of development progress. GMM estimation yields a smaller magnitude of this factor, but still significant.

Our advanced analysis also shows a reversal in the sign of capital formation. Fixed effect and GMM regressions equally report that investment positively impacts tax ratio, and has high significance. This is in contrast compared to the baseline result. Nonetheless, the results give us more confidence to support our hypothesis. Domestic investment contributes significantly to improving the country's tax ratio, as reflected in the gross capital formation figure.

All other variables lose their significance in the latter specifications. Moreover, almost all variables also suffer shrinkage in the scale of their coefficients. This circumstance highlights the notorious difficulty in a cross-country analysis of tax ratio. Despite our effort to control several factors and mitigate possible biases, variation in each country's performance cannot be easily explained. We do recognize that many other things may also have contributions, such as sociopolitical characteristics. However, the figures may not always be available or readily available and comparable.

Sub-sample Analysis

An analysis with a large pool of country samples understandably could give a very different picture over a long time compared to the smaller scale. Therefore, we complement our worldwide analysis by running the same specifications on a smaller number of countries based on income level category. This study does not discuss the World Bank criteria to segregate the countries and their possible consequences. We refer to the recent status for the sake of simplicity.

Our OLS regression results show that each factor's direction and significance are in general consistent regardless of the income status. Several differences are noteworthy to be highlighted. First, GDP per capita and governance are greatly more influential in high-income countries. These factors combined far outweigh the impact of other variables. A possible explanation of this phenomenon is that as society grew more prosperous, they demand higher level and quality of services from the government. Thus, the size of government also increases parallel with the governance.

Another point worth mentioning is that the agriculture share in advanced economies has an opposite impact and much bigger coefficient than the same sector in lower-income countries. It is a fact that farming, forestry, and fishery in high-income countries operate on a large scale. Not only are 
these economic activities operated with high technology and yield high productivity, the players are also registered and regulated. Hence the taxes can be easily collected, which is not the case in developing countries. However, we should be careful since our further analysis using the fixed effects implied adverse effects.

Next, capital formation and trade openness have more impact on low and lower-middle-income than in wealthier countries. Private and public investment and a more open market could stimulate vibrant economic activities. Looking at the recent trend of indirect taxes (GST/VAT) implementation in developing countries, the tax ratio improvement through these channels can be logically explained.

In addition, natural resource endowment can be a blessing from the taxation perspective. While these countries cannot rely on taxing agriculture, they tap more benefit in terms of tax receipts from investment, trade, and natural resource exploitation.

\section{CONCLUSION AND RECOMMENDATIONS}

Considering the importance of tax revenue collection in most parts of the world, we conducted an empirical analysis to shed more light on the tax ratio determinants. We reconsidered several structural, economic, demographic, and institutional factors that potentially explain why some countries manage to mobilize a higher level of taxes while some lagged behind. Our findings confirmed that the level of development and investment have strong nexus with tax revenue. Other factors such as trade openness, inflation, informal economy, national resources, population, and governance cannot be downplayed despite its mixed inferences.

Policymakers may want to direct their policies to support improvement in these areas, shall they want to lift tax to GDP ratio to a more sustainable level. Broad recommendation are as follows: providing an investment-friendly environment by introducing well-aimed incentives, promoting more engagement in international trade by actively participating in free trade agreements, keeping steady price level through inflation control measures, stimulating the shift from informal economic activities (including shifting traditional to modern agriculture,) gradually decreasing reliance on natural resource exploitation, managing demographic issues wisely, and improving all aspects of good governance. By no means intending to undermine the ongoing COVID-19 pandemic, attention should also be given to such efforts. The long-term fiscal sustainability is too high a risk if tax revenue does not recover to or exceed the pre-pandemic height.

From the academic perspective, we realize that the tax ratio's causal inference has not been fully addressed. Therefore, this study could be extended using more rigorous techniques. The inclusion of other potential explanatory variables is highly recommended. On top of that, we suggest using this worldwide comparative as a departing point before embarking on a country or a regional-specific analysis.

\section{ACKNOWLEDGEMENT}

Financial support from the Government of Indonesia through LPDP scholarship is gratefully acknowledged.

\section{REFERENCES}

Agbeyegbe, T., Stotsky, J. G., \& WoldeMariam, A. (2004). Trade Liberalization, Exchange Rate Changes, and Tax Revenue in Sub-Saharan Africa. IMF Working Paper, WP/04/178.

Ajaz, T., \& Ahmad, E. (2010). The Effect of Corruption and Governance on Tax Revenues. The Pakistan Development Review, 49(4), 405-417. Retrieved from http://www.jstor.com/stable/41428665

Arellano, M., \& Bond, S. (1991). Employment Equations Some Tests of Specification for Panel Data: 
Monte Carlo Evidence and an Application to Employment Equations. The Review of Economic Studies, 58(2), 277-297. Retrieved from https:/www.jstor.org/stable/2297968

Bahl, R. (2004). Reaching the Hardest to Tax: Consequences and Possibilities. In S. Alm, James; Martinez-Vazquez, Jorge; Wallace (Ed.), Taxing the Hard-to-Tax: Lessons from Theory and Practice. - (Contributions to Economic Analysis 268) (pp. 338-354). Elsevier B.V.

Baunsgaard, T., \& Keen, M. (2010). Tax revenue and (or?) Trade Liberalization. In Journal of Public Economics (Vol. 94, pp. 563-577). Elsevier B.V. https://doi.org/10.1016/j.jpubeco.2009.11.007

Bird, R. M., Martinez-vazquez, J., \& Torgler, B. (2014). Societal Institutions and Tax Effort in Developing Countries. Annals of Economics and Finance, 15(1), 185-230.

Blundell, R., \& Bond, S. (1998). Initial Conditions and Moment Restrictions in Dynamic Panel Data Models. Journal of Econometrics, 87, 115-143.

Castañeda Rodríguez, V. M. (2018). Tax Determinants Revisited. An Unbalanced Data Panel Analysis. Journal of Applied Economics, 21(1), 1-24. https://doi.org/10.1080/15140326.2018.1526867

Chelliah, R. J., Baas, H. J., \& Kelly, M. R. (1975). Tax Ratios and Tax Effort in Developing Countries. Staff Papers (International Monetary Fund), 22(1), 187-205. Retrieved from http://www.jstor.com/stable/3866592

Grigorian, D. A., \& Davoodi, H. R. (2007). Tax Potential vs. Tax Effort: A Cross-Country Analysis of Armenia's Stubbornly Low Tax Collection. IMF Working Papers, 07(106), 1-38. https://doi.org/10.5089/9781451866704.001

Gupta, A. Sen. (2007). Determinants of Tax Revenue Efforts in Developing Countries. IMF Working Paper, WP/07/184.

ILO. (2018). Women and Men in the Informal Economy: A Statistical Picture (Third Edition). Geneva. Retrieved from https://www.ilo.org/global/publications/books/WCMS_626831/lang-en/index.htm

Khujamkulov, I. (2016). Tax revenues in Transition Countries. UNU-WIDER Working Paper, 180.

Lotz, J. R., \& Morss, E. R. (1967). Measuring "Tax Effort " in Developing Countries. Staff Papers (International Monetary Fund), 14(3), 478-499. Retrieved from http://www.jstor.com/stable/3866266

McNabb, K. (2018). Tax Structures and Economic Growth: New Evidence from The Government Revenue Dataset. Journal of International Development, 30, 173-205. https://doi.org/10.1002/jid.3345

Prichard, W. (2016). Reassessing Tax and Development Research: A New Dataset, New Findings, and Lessons for Research. World Development, 80, 48-60. https://doi.org/10.1016/j.worlddev.2015.11.017

Syadullah, M., \& Wibowo, T. (2015). Governance and Tax Revenue in Asean Countries. Journal of Social and Development Sciences, 6(2), 76-88. https://doi.org/10.22610/jsds.v6i2.845

Tanzi, V. (1977). Inflation, Lags in Collection, and the Real Value of Tax Revenue. Staff Papers (International Monetary Fund), 24(1), 154-167. Retrieved from http://www.jstor.com/stable/3866540

Yogo, U. T., \&e Njib, M. M. N. G. O. (2018). Political Competition and Tax Revenues in Developing Countries. Journal of International Development, 30, 302-322. https://doi.org/10.1002/jid.3349 